\title{
Known Distribution of the Soybean Cyst Nematode, Heterodera glycines, in the United States and Canada, 1954 to 2017
}

Gregory L. Tylka ${ }^{\dagger}$ and Christopher C. Marett, Department of Plant Pathology and Microbiology, lowa State University, Ames 50011

Accepted for publication 19 June 2017.

The soybean cyst nematode (SCN), Heterodera glycines Ichinohe, remains a major yield-reducing pathogen of soybeans, Glycine max L. Merr., in North America more than 60 years after its first discovery in the United States, in North Carolina in 1954 (Winstead et al. 1955). The nematode recently was ranked as the most damaging soybean pathogen in the United States and Canada (Allen et al. 2017). SCN is believed to have been introduced to the United States from Asia (Noel 1992; Riggs 2004), and as an introduced pest, knowledge of the distribution of SCN can be helpful in identifying areas where scouting and management efforts should be focused. Such information is especially important for SCN because yield-reducing infestations can occur without obvious above-ground symptoms (Wang et al. 2003).

Maps identifying known SCN-infested counties in the United States and Canada have been compiled at numerous times since the 1950s. The most recent map was published in Plant Health Progress in 2014 (Tylka and Marett 2014).

Since 2014, SCN was found for the first time in numerous additional counties in several states. Therefore, nematologists, plant pathologists, and state plant regulatory officials from the soybean-producing areas of the United States and Canada were contacted in late 2016 and asked to provide updated information on which counties or provinces were known to be infested with SCN.

Seventeen states (Table 1) reported that SCN was found for the first time in one or more counties since 2014. Also, there were a few counties in which SCN had been discovered prior to 2014 but had not previously been reported that were added to the updated map (Fig. 1). A total of 37 counties were added to the map for 2017 that were not on the map published in 2014 (Supplementary Fig. S1).

North Dakota had the greatest number of counties, seven, newly identified since 2014 as SCN-infested. The most noteworthy newly infested county, discovered in 2016, was Cayuga County, New York, because it was the first confirmed discovery of SCN in that state (Wang et al. 2017). Also notable was the infestation found in

${ }^{\dagger}$ Corresponding author. E-mail: gltylka@iastate.edu

*The $\boldsymbol{e}$-Xtra logo stands for "electronic extra" and indicates that one supplementary figure is published online.

(C) 2017 The American Phytopathological Society

\begin{tabular}{lclc} 
TABLE 1 \\
$\begin{array}{l}\text { Number of counties infested with the soybean cyst } \\
\text { nematode (SCN) that were added to the known distribution } \\
\text { of SCN } \\
\text { map from }\end{array}$ & $\begin{array}{l}\text { 2014 to } \\
\text { 2017, by state } \\
\text { Counties added } \\
\text { since } 2014\end{array}$ & State & $\begin{array}{c}\text { Counties added } \\
\text { since 2014 }\end{array}$ \\
State & 1 & New Jersey & 2 \\
Alabama & 3 & New York & 1 \\
Georgia & 1 & North Carolina & 3 \\
Indiana & 1 & North Dakota & 7 \\
Iowa & 3 & Ohio & 3 \\
Kansas & 3 & South Dakota & 1 \\
Kentucky & 2 & Virginia & 2 \\
Minnesota & 1 & Wisconsin & 1 \\
Missouri & 2 & & \\
Nebraska & & & \\
\hline
\end{tabular}

Allamakee County, Iowa, in 2016; that county had been the only one in Iowa in which SCN had not yet been found (Tylka and Lang 2017). However, as in 2014, SCN was not yet found in the soybeanproducing U.S. state of West Virginia or the soybean-producing Canadian provinces of Prince Edward Island and Manitoba (Tenuta et al. 2016).

When using the maps, one should consider that SCN may be present in more counties than are indicated as infested, particularly because SCN has been shown to infest fields without causing above-ground symptoms (Wang et al. 2003). Also, discovery of SCN in a single field in a county results in the county being designated infested on the map, but does not provide any information about the prevalence or geographic distribution of SCN infestations within a county. Infestations within counties designated as infested may be isolated, widespread, or something in between. Finally, it should be noted that no efforts were made to reconfirm infestations that were discovered in counties long ago in which soybeans are no longer grown, such as in Florida. The map published herein and those published by Tylka and Marett in 2014 illustrate the cumulative known distribution of SCN in the United States and Canada, not the current known distribution.

\section{Acknowledgments}

We thank the plant nematologists, plant pathologists, and state plant health regulatory officials from the United States and Canada who provided information about the known distribution of the soybean cyst nematode in their areas. 


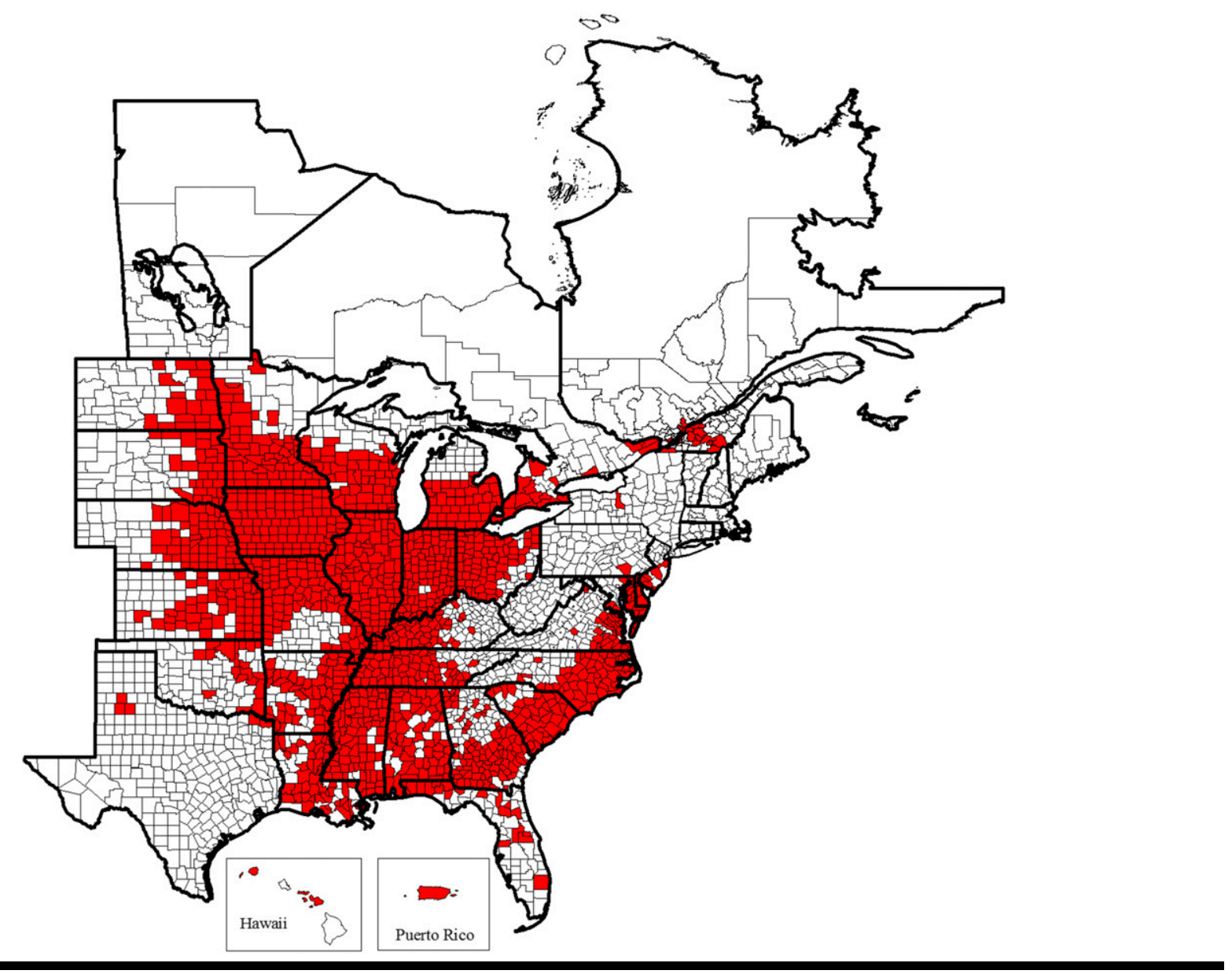

FIGURE 1

Map of the known distribution of the soybean cyst nematode, Heterodera glycines, in the United States and Canada from 1954 to 2017. Known infested counties are indicated in red. Map ๑ C. C. Marett and G. L. Tylka, lowa State University, 2017.

\section{Literature Cited}

Allen, T. W., Bradley, C. A., Sisson, A. J., Byamukama, E., Chilvers, M. I., Coker, C. M., Collins, A. A., Damicone, J. P., Dorrance, A. E., Dufault, N. S., Esker, P. E., Faske, T. R., Giesler, L. J., Grybauskas, A. P., Hershman, D. E., Hollier, C. A., Isakeit, T., Jardine, D. J., Kelley, H. M., Kemerait, R. C., Kleczewski, N. M., Koenning, S. R., Kurle, J. E., Malvick, D. K., Markell, S. G., Mehl, H. L., Mueller, D. S., Mueller, J. D., Mulrooney, R. P., Nelson, B. D., Newman, M. A., Osborne, L., Overstreet, C., Padgett, G. B., Phipps, P. M., Price, P. P., Sikora, E. J., Smith, D. L., Spurlock, T. N., Tande, C. A., Tenuta, A. U., Wise, K. A., and Wrather, J. A. 2017. Soybean yield loss estimates due to diseases in the United States and Ontario, Canada, from 2010 to 2014. Plant Health Prog. 18:19-27.

Noel, G. R. 1992. History, distribution, and economics. Pages 1-13 in: Biology and Management of the Soybean Cyst Nematode. American Phytopathological Society, St. Paul, MN.

Riggs, R. D. 2004. History and distribution. Pages 9-39 in: Biology and Management of Soybean Cyst Nematode, 2nd Ed. Schmitt \& Assoc. of Marceline, Marceline, MO.
Tenuta, M., Madani, M., Peirera, F., and Hajihassani, J. 2016. Survey says: No soybean cyst nematode, Heterodera glycines Ichinohe, in Manitoba. J. Nematol. 48: 376.

Tylka, G., and Lang, B. 2017. Last county in Iowa found infested with SCN. Integ. Crop Manage. News 2343. Coop. Ext., Iowa State Univ., Ames. http:// lib.dr.iastate.edu/cropnews/2343

Tylka, G. L., and Marett, C. C. 2014. Distribution of the soybean cyst nematode (Heterodera glycines) in the United States and Canada: 1954 to 2014. Plant Health Prog. 15:85-87.

Wang, J., Niblack, T. L., Tremaine, J. N., Wiebold, W. J., Tylka, G. L., Marett, C. C., Noel, G. R., Myers, O., and Schmidt, M. E. 2003. The soybean cyst nematode reduces soybean yield without causing obvious symptoms. Plant Dis. 87:623-628.

Wang, X., Bergstrom, G. C., Chen, S., Thurston, D. M, Cummings, J. A., Handoo, Z. A., Hult, M. N., and Skantar, A. M. 2017. First report of the soybean cyst nematode, Heterodera glycines, in New York. Plant Dis. http:// dx.doi.org/10.1094/PDIS-06-17-0803-PDN.

Winstead, N. N., Skotland, C. B., and Sasser, J. N. 1955. Soybean cyst nematode in North Carolina. Plant Dis. Rep. 39:9-11. 